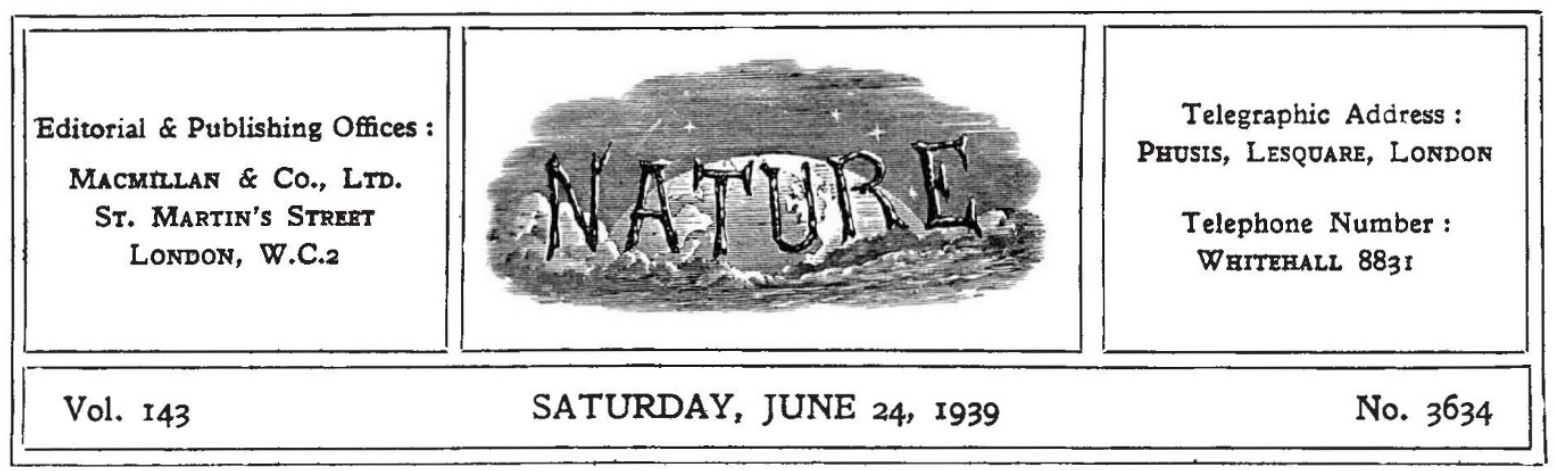

\title{
Population Problems in Relation to Refugees
}

W HETHER as indicated by the support accorded to the work of the Society for the Protection of Science and Learning, or by the care taken of individual refugees in particular universities, and the efforts made to find opportunities for men of learning to continue their teaching and investigations, the universities of Great Britain have nobly accepted their responsibilities and shouldered burdens which have often involved individuals in real sacrifice. By the universities at least this practical task of caring for refugee men of science and learning has been recognized as an inseparable part of the task of preserving for mankind its full privileges of freedom of thought and investigation. Nevertheless, Sir John Hope Simpson can conclude in his study of the refugee problem* that Great Britain's record in the admission of refugees is not distinguished when compared with that of France, Czechoslovakia or the United States of America.

Even in academic circles, however, the problem has rarely been considered on wider grounds than those of humanitarianism and the defence of freedom of thought and learning. For this reason alone the admirable dispassionate survey of the refugee problem as a whole which has been conducted under the auspices of the Royal Institute of International Affairs is welcome. This carefully prepared and lengthy report gives an exhaustive study of the origins and course of refugee movements as well as a record of the methods adopted internationally and by individual Governments, and of the immense efforts made by the great philanthropic organizations.

* The Refugee Problem : Report of a Survey. By Sir John Hope Simpson. (Issued under the auspices of the Royal Institute of International Affairs.) Pp. $x v+637$, (London, New York and Toronto: Oxford University Press, 1939.) 258. net.
The scope of the survey is restricted to postWar movements which originated in European countries, in the Ottoman Empire and in the Russian Empire, and refugee movements arising from natural causes such as earthquake or flood are also excluded. For all these limitations, the survey gives us the essential background for assessing the significance of the refugee problem and the many factors which are involved in it, as well as the various solutions proposed and the obstacles to such solutions and to the movement or absorption of refugees.

One of the great merits of this survey is the way in which the problem is presented in its true perspective. Indeed it might be true to say that the absence of a sense of perspective has been one of the main factors in creating the refugee problem. The American quota system, the British immigration laws and the virtual closing to immigration of the British Dominions have been the chief factors which issued in the refugee problem. Sir John Simpson makes it abundantly plain how the stopping of these safety valves has led to population pressures which have profoundly influenced the course of post-War history. Markets have ceased to expand, and labour in the more privileged countries is anxious to defend its standards of living against cheap immigrant competition. The spread of State control over every aspect of life in itself tends to render nationalism more readily inflamed.

The refugee problem accordingly cannot be detached from population and migration questions generally. However strongly we may reprobate the immediate political causes of a particular refugee movement, or however justly the conduct or policy of a particular ruler or nation is to be 
condemned, such causes rarely stand entirely alone. The disappearance of the right of asylum and of laissez faire liberalism from the policy of Great Britain even ten years before the Great War are contributory factors which should make us defer hasty judgment.

There are, moreover, various points upon which further ad hoc scientific inquiry is desirable. Information as to the economic effect of refugee immigration is not entirely adequate. Inquiries in Holland and Belgium suggest that in these countries the advent of refugees has resulted in the employment of nationals in numbers greater than the refugee influx. In Great Britain the fur trade appears to have gained by the transfer of Jewish business from Leipzig to London, and it has been stated by the Home Secretary in the House of Commons that as a result of the settlement of eleven thousand refugees in Great Britain, employment has been given to about fifteen thousand British workers who would not otherwise have been employed. Sir John Hope Simpson says that the number of British workers employed as a result of German inamigration is at least twice the number of refugees themselves.

Numerous cases are known in which new manufacturing businesses have been initiated by immigrants, but there are many other inluences at work and the contributions made by refugee scholars and men of science are difficult to assess. The question would justify a full investigation. Already there is evidence to show that the presumption that the admission of immigrants is likely as a rule to increase unemployment is by no means so well-founded as may at first sight appear. The element of consumption has to be taken into account. It is indeed impossible to determine whether the admission of immigrants is more likely in general to increase or to diminish unemployment. The answer depends partly upon the particular industrial aptitude of the immigrants and partly on the economic circumstances prevailing at the time in the country they enter.

The question has accordingly to be considered, not on hard and fast rules, but in relation to the general employment and population trends in the country admitting the refugees. When reasonably active conditions of trade prevail, unemployment may be reduced by a freer admission of immigrants if these are likely to be suitable for the occupations where the supply of labour is relatively scarce. Such a principle must, however, be applied in a generous and not in a narrow-minded spirit.
Fairly considerable unemployment figures in a particular occupation can easily co-exist with a genuine shortage of labour, partly because of the small margin of workers of low industrial aptitude always to be found, partly because distinct types of work are often included under the same occupational designation, partly because of regional differences or seasonal and other temporary fluctuations. In many countries, even during the recent recession of trade, shortage of labour in certain industries connected with the production of armaments has persisted. A readier admission of immigrants who would have met the needs of these industries even during this period might have been economically advantageous, apart from its beneficial effect on defence preparations.

From this point of view, decisions taken under the influence of an unsatisfactory state of trade may accordingly prove premature and unwise, apart from all humanitarian considerations. Population questions generally, however, make longrange views and policies even more important. The admission of refugees to Great Britain or any other country eannot be wisely considered without regard to the imminence of declining population and its economic results, the consequences of which would appear to be almost completely ignored by the public and the Government alike. The problems of a declining population, with the consequent difficulties of economic adjustment, are in urgent need of scientific investigation and treatment. Industry, for example, has largely ignored the warnings about the effect of a lower birth-rate on the number of those leaving school and on industrial recruitment, and has scarcely begun to formulate plans to meet a shortage of juvenile labour which has been foretold for more than a decade. A scientific investigation of such problems and of the contribution which immigration policy might offer in minimizing some of the difficulties might well lead to a policy towards the admission of refugees both more generous and humane and more economic and scientific.

Sir John Simpson's report leaves no room for doubt as to the need for further impartial investigation of the questions which are linked up with the refugee problem. It may well make some professional associations uncomfortably aware of their own neglect or selfishness, or both. There is no single or simple solution save that of time, and the report should prevent premature or unsound conclusions being drawn from the solution of the problem of the Greek and Bulgarian refugees, for 
example. Colonization on a large scale appears to be impracticable, but the problem would be reduced if more active steps were taken to train refugees in countries of temporary refuge, instead of maintaining them in idleness, and to pass them on to countries of permanent settlement as opportunity arises.

If, however, there are directions in which further investigation might yield invaluable results, the immediate problem, Sir John Simpson insists, is action. The machinery for Government action was created at Evian in July 1938, and the steps that are most urgently required are no longer those which can be taken by private organizations. The purposeful training of intending immigrants under good conditions which maintain their health and morale; the provision of capital for opening up areas not yet developed and for the necessary institutions of civilization are steps which can only be taken by Governments. Sir John believes that if Great Britain and France and some other European countries such as Norway, Sweden, Denmark, Belgium, Holland and Finland, were to agree to take a quarter of the potential refugees from Germany at once, and accommodate them if necessary in camps until they could be dispersed to countries of ultimate settlement, a substantial step would have been taken towards solution of the problem.
This considered judgment of the report that much more than private charity is essential does not, of course, imply that there are no longer directions in which such assistance should not continue to be given. Apart from their share in the work of the universities in the relief of refugee scholars, scientific workers have particular responsibilities in some of the fields of inquiry indicated above. They must be responsible for the conduct of some of the investigations, and pressure from them might well assist to stimulate the initiation of such investigations. Moreover, the report itself might well stir them to re-examine the narrow view of the problem which has characterized some of their professional associations.

Beyond this, scientific workers have the common interest of all citizens in the policy of their Government in this matter. The post-War immigration policy of Great Britain has been exceedingly cautious. It is at least open to argument that a more generous policy might prove in the long run to be wise and sound from the economic point of view, in that it might offer a contribution to the solution of the very serious problems with which we are confronted in the immediate future through our declining population; while there can be no question that the calls of humanity require us to do all within our power to alleviate the distress inevitably associated with the refugee problem.

\section{Haldane as Strategist, Educationist and Philosopher}

\section{Haldane, I915-I938}

The Life of Viscount Haldane of Cloan, K.T., O.M. By Major-General Sir Frederick Maurice. Pp. $\mathrm{xv}+290+8$ plates. (London: Faber and Faber, Ltd., 1939.) 18s. net.

HALDANE'S epitaph describes him, proudly but not unjustly, as "A great servant of State who devoted his life to the advancement and application of knowledge. Through his work in fashioning her army he rendered invaluable aid to his country in her time of direst need". The word "fashioning" is peculiar but possibly appropriate. Controversy turns on the use of the Army "fashioned" by Haldane. In 1905, when Haldane first took office, as Secretary for War, there was lack of co-operation between the navy and army on strategical questions. In January 1906, the question of co-operation with the French Army was raised, and Huguet brought back from the
French War Office two proposals for the British Army : (1) être liée à celle de l'armée française, and (2) se faire sentir dès le début des hostilités. Colonel Lawrence, the uncrowned King of Arabia, says of the French that the only way to deal with them is to say "hoots" to them. Sir Henry Wilson, who beoame Haldane's principal adviser on strategical questions, was a francophile, more disposed to say this word to the politicians than to the French. Sir Edward Grey, on January 15, 1906, in a letter to Sir F. Bertie, British Ambassador in Paris, had said the word in diplomatic language -our military contribution "won't save France unless she can save herself". Haldane gave unflinching support to Wilson's strategy, notwithstanding strong opposition from Fisher and the 'blue water' school and from Lord Roberts and the conscriptionists. "Pussy", to give Haldane his nickname, turned tiger on occasion. Lord Riddell states in his diary that Mr. McKenna, 